\title{
Hepatocellular Carcinoma: The Role of Interventional Oncology
}

\author{
Matteo Donadon ${ }^{a} \quad$ Luigi Solbiati $^{\mathrm{b}} \quad$ Laura Dawson $^{\mathrm{c}}$ \\ Aisling Barryc Gonzalo Sapisochin ${ }^{d}$ Paul D. Greig ${ }^{d}$ \\ Shuichiro Shiinae Andrea Fontana ${ }^{a}$ Guido Torzillia
}

aDepartment of Hepatobiliary and General Surgery, Humanitas University, Humanitas Research Hospital IRCCS, bDepartment of Interventional Radiology, Humanitas University, Humanitas Research Hospital IRCCS, Milan, Italy, 'Department of Radiation Oncology, University of Toronto, Princess Margaret Cancer Centre, dDeparments of General Surgery and Multi Organ Transplantation, Toronto General Hospital, University of Toronto, Toronto, Canada, eDepartment of Gastroenterology, Juntendo University Graduate School of Medicine, Tokyo, Japan

\section{Key Words}

IRE for HCC · MWA for HCC · Radiotherapy for HCC - RFA for HCC

\begin{abstract}
Background: Hepatocellular carcinoma (HCC) remains a major health issue because of its increasing incidence and because of the complexity of its management. In addition to the traditional potentially curative treatments, i.e., liver transplantation and surgical resection, other new and emerging local therapies have been applied with promising results. Summary: Radiotherapy (RT) and interstitial treatments, such as radiofrequency ablation (RFA), microwave ablation (MWA), and irreversible electroporation (IRE), have recently opened new and interesting treatment scenarios for HCC and are associated with promising results in selected patients. Herein, we describe the emerging role of interventional oncology for the treatment of HCC and focus on the different Western and Eastern approaches. Key Messages: Modern RT and modern interstitial therapies, such as RFA, MWA, and IRE, should be considered for inclusion in HCC therapy guidelines.

Copyright $(2016$ S. Karger AG, Basel
\end{abstract}




\section{Introduction}

Hepatocellular carcinoma (HCC) is the fifth most common cancer and the third most common cause of cancer-related deaths worldwide [1]. Its treatment remains a major health issue because of its increasing incidence and because of the complexity of its management. In addition to liver transplantation and surgical resection, which are considered the standard of care for patients who satisfy specific inclusion criteria [2,3], other new and emerging local therapies have been recently applied with promising results. The present work describes the emerging role of interventional oncology for the treatment of HCC.

\section{Radiotherapy (RT) in the Management of HCC}

Historically, since tumoricidal radiation doses cannot be delivered safely to the whole liver, radiation oncologists have shied away from managing HCC with RT because of fears of radiation-induced liver disease. The lingering fear of RT-associated toxicity may be attributable to past inferior and inefficient RT techniques requiring irradiation of the full liver by upper abdominal RT. However, with improved imaging technologies [multiphasic liver computed tomography (CT) and magnetic resonance imaging (MRI) and image registration software] and radiation technologies [from 3D conformal radiation therapy to stereotactic body radiotherapy (SBRT)], there has been a significant reduction in the volume of normal tissue exposed to radiation during treatment. As a result, there is great potential for ablative doses to be delivered to focal HCC of various stages, as long as sufficient liver may be spared from harmful exposure to radiation.

Liver RT uses multiphasic and multimodality imaging to develop a model of the lesion and of the adjacent organs, so that the prescribed doses of RT conform to the target volume; RT is most often delivered in 20-30 daily doses (fractions) over 4-7 weeks. SBRT, the most common RT treatment for HCC, applies a high dose of highly conformal radiation generally delivered in 3-6 treatment fractions over a far shorter time, in conjunction with breathing motion management strategies and daily image guidance at the time of RT delivery (IGRT). IGRT has been facilitated by the development of linear accelerators integrated with conebeam CT; MRI integrated treatment units are under development and are planned for clinical use for liver cancer in 2016.

Similar to all HCC management strategies, hepatic RT is highly personalized. The irradiated volumes, tumor dose, number of fractions, breathing motion management strategy, and IGRT technique are dependent on patient factors (e.g., performance status and Child-Pugh score) and tumor factors (e.g., HCC size, number of lesions, location of lesions, and liver volume).

\section{RT as a Bridge to Liver Transplantation}

Up to $15 \%$ of newly diagnosed HCC patients are potentially curable with liver transplantation, which is the optimal therapy for HCC patients with underlying cirrhosis. Unfortunately, approximately $20-30 \%$ of these patients experience progression of their HCC while on the waiting list, rendering them unsuitable for transplantation. Bridging therapies are therefore often considered for patients with HCC during the pre-transplant wait period. Alternatively, for patients with HCC that exceeds size guidelines for transplantation, therapies are sometimes given with the goal of downstaging the HCC so that it falls within transplant guidelines (e.g., the Milan criteria). 
Table 1. Selected series of SBRT for early stage HCC

\begin{tabular}{|c|c|c|c|c|c|c|c|c|}
\hline $\begin{array}{l}\text { Author, year } \\
\text { [reference] }\end{array}$ & $\begin{array}{l}\text { Patient } \\
\text { number }\end{array}$ & $\begin{array}{l}\text { Tumor size } \\
(\mathrm{cm})^{*}\end{array}$ & $\begin{array}{l}\text { RT dose } \\
\text { (Gy) }\end{array}$ & $\begin{array}{l}\text { Number of } \\
\text { fractions }\end{array}$ & $\begin{array}{l}\text { Median } \\
\text { follow-up } \\
\text { (months) }\end{array}$ & $1-Y$ OS & $3-Y$ OS & $\begin{array}{l}\geq \mathrm{G} 3 \\
\text { hepatic } \\
\text { toxicity }\end{array}$ \\
\hline $\begin{array}{l}\text { Sanuki, } 2013 \\
\text { [8] }\end{array}$ & 185 & $\begin{array}{l}2.5 \\
0.8-5\end{array}$ & 40 & 5 & 24 & $95 \%$ & $70 \%$ & $13 \%$ \\
\hline $\begin{array}{l}\text { Yoon, } 2013 \\
\text { [9] }\end{array}$ & 93 & $\begin{array}{l}2 ; \\
1-6\end{array}$ & $30-40$ & $3-4$ & 25.6 & $86 \%$ & $54 \%$ & $6.5 \%$ \\
\hline $\begin{array}{l}\text { Kwon, } 2010 \\
{[10]}\end{array}$ & 42 & $\begin{array}{l}15.4 ; \\
3-81.8\end{array}$ & $30-39$ & 3 & 28.7 & $92 \%$ & $58 \%$ & $0 \%$ \\
\hline
\end{tabular}

Y=year. *Values are the median and range.

Traditionally, transcatheter arterial chemoembolization (TACE) and RFA have been the most commonly used bridging or downstaging treatments. However, there is emerging interest in the use of RT, specifically SBRT, as a bridging therapy, especially for patients not well suited to RFA or TACE. Previous studies have shown the efficacy of SBRT as a bridge to liver transplantation [4-6]. Currently, at the University of Toronto, SBRT is being compared to TACE as a bridging therapy for HCC patients [7-10]. The preliminary analysis of that study (unpublished data) showed that of 311 patients with HCC listed for liver transplantation who underwent bridging therapy, 107 received either SBRT $(n=23)$ or TACE $(n=84)$. Patients in the SBRT group had more advanced liver disease that precluded TACE. No differences were observed between groups in the drop-out rate, in the actuarial survival after liver transplantation, or in the disease-free survival (DFS) after liver transplantation. Our ongoing analysis of 39 patients treated with SBRT as a bridge to transplantation suggests that SBRT (median dose 36 Gy in six fractions) can be delivered as a bridging therapy with no increase in toxicity at the time of transplantation.

RT as a Potential Radical Treatment in Early and Intermediate Stage HCC

Poor underlying liver function and/or comorbidities render the majority of HCC patients inoperable. Patients with small tumors (e.g., $<3 \mathrm{~cm}$ ) are best suited to RFA or local ablative treatments. Although TACE is the standard recommended treatment for patients unsuitable for RFA, TACE is not a curative treatment option. RT alone (without TACE) has been used with curative intent to treat early stage HCC, with promising outcomes (table 1).

Similar outcomes have been observed following proton RT [11], showing the potential for RT to achieve sustained control of HCC and improved long-term survival. These data indicate that for early stage HCC patients unsuitable for surgery, transplantation, RFA, or TACE, RT should be strongly considered; studies of RT in this setting in the Western world are much needed.

RT and TACE have also been delivered as planned combination therapy for early and intermediate stage HCC. Guo et al. [12] concluded that TACE alone was inferior to combination therapy: significantly higher response rates were evident for combination therapy than for TACE alone (47.4\% vs $28.1 \%$ ) and TACE combined with RT achieved overall survival (OS) rates at 1 and 3 years of $64.1 \%$ and 28.6\%, respectively. Meng et al. [13] also showed superiority with combined TACE and RT in their meta-analysis of 1276 patients; however, welldesigned phase III studies of TACE and RT have not been conducted. 


\section{Liver Cancer}

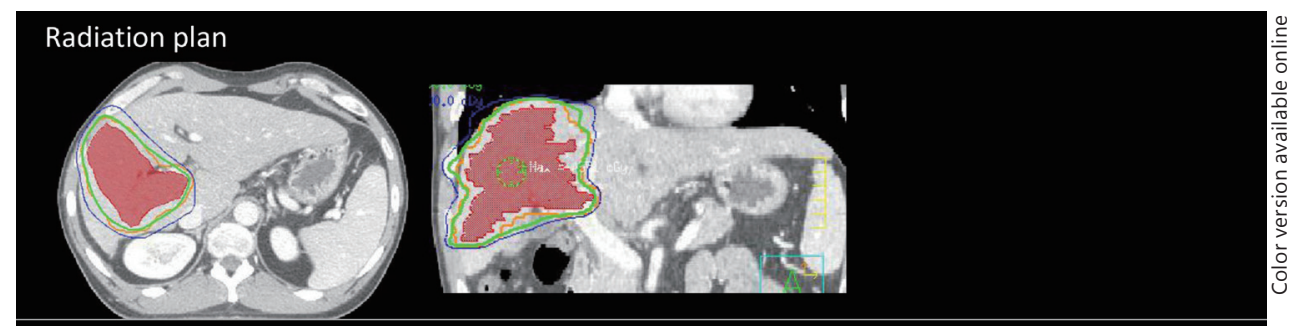

Baseline imaging
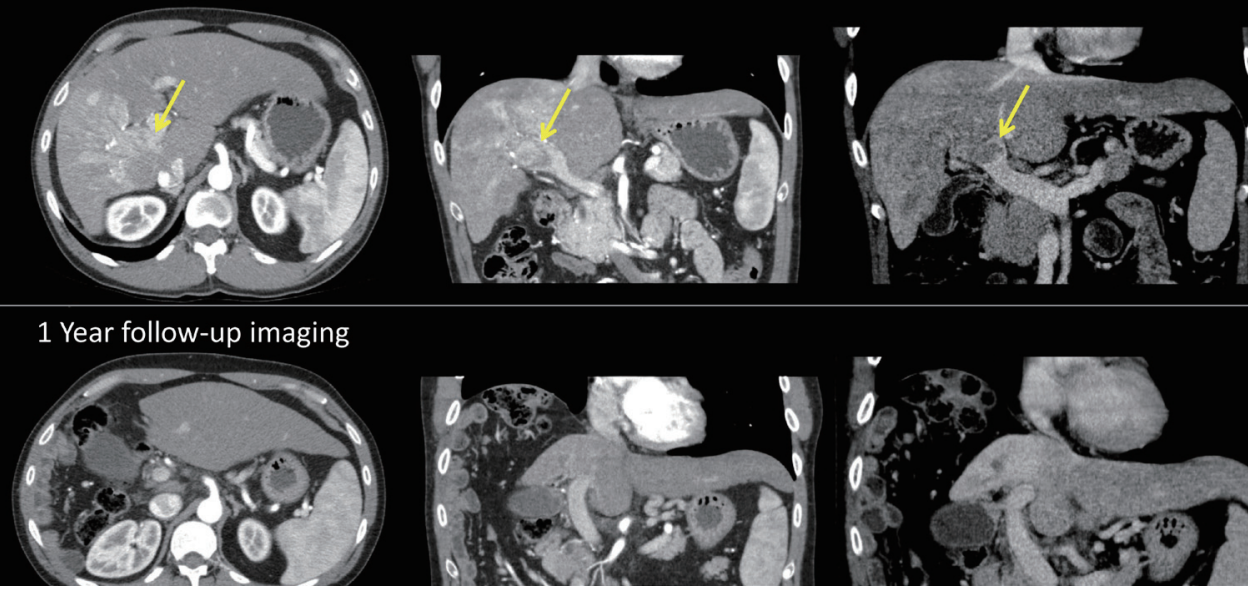

Fig. 1. Example of a typical radiation plan for a patient with HCC and vascular invasion. The radiation plan is for an HCC patient with hepatitis C and HIV. HCC (red) with invasion to the right portal vein (yellow arrow) was treated with 35 Gy in five fractions (green line). Baseline and follow-up arterial-phase and delayed-phase CT scans demonstrate an excellent radiographic response that was mirrored by an excellent clinical response and stable liver function 1 year after SBRT. At the last follow-up, there was no active HCC and the irradiated right lobe had atrophied.

\section{TACE}

RT for Locally Advanced HCC, Including Vascular Invasion and Disease Progression after

There have been a number of SBRT series and phase II clinical trials that have investigated the use of RT alone to treat predominantly locally advanced HCC [11, 12]. Patients with recurrences following standard local regional therapies, those ineligible for standard therapies, and (less commonly) patients with a low burden of metastatic HCC, have been the focus of other RT studies. Studies have demonstrated high rates of local control, including control of vascular HCC, and promising survival rates, e.g., median survival of 17 months [14-16]. An example of a typical radiation plan for a patient with HCC and vascular invasion, and the subsequent response, is shown in fig. 1.

It is important to note that there is risk of a decline in liver function at 3 months (10$30 \%$ ) in these patients. Thus, randomized controlled trials are essential in helping to understand the benefits versus the risks of RT in this setting.

\section{$R T$ in Conjunction with Chemotherapeutic Agents}

TACE alone is not a curative therapy. However, Shim et al. [17] showed that TACE in conjunction with RT resulted in an increased 2-year survival of $36.8 \%$ vs $14.3 \%$ in patients with stage III or IVa disease. Survival rates have also been shown to improve from 7.9 to 10.2 months in patients with locally advanced unresectable HCC treated with sorafenib [18], the only molecular targeted agent approved in the management of locally advanced and metastatic HCC unsuitable for TACE. Evidence for a synergistic effect of RT and sorafenib therapy 
[19] and the results of a phase II trial [20] have suggested that, compared to concurrent RT and sorafenib, sequential RT and sorafenib is an attractive strategy to improve tumor control while keeping the risk of additional toxicity to a minimum. These findings, and those of a series of SBRT alone, support RTOG 1112, a multi-institutional prospective randomized controlled trial to compare sorafenib alone and SBRT followed by sorafenib. RTOG 1112 is currently actively recruiting Child-Pugh A HCC patients who are unresectable or unsuitable for transplantation, resection, RFA, TACE, or drug-eluting bead therapy [21].

\section{RT as Palliation for Symptomatic HCC and Metastatic Disease}

Bleeding, pain related to a bulky tumor or rupture, and the prevention of pending tumor rupture are recognized indications for palliative RT in HCC patients. The use of RT in metastatic HCC (outside of the liver) is common, and the results are often beneficial because HCC is generally a radiation-responsive tumor. However, the data supporting the use of whole-liver low-dose RT for palliation of symptoms is limited. Using validated patient-reported outcomes, a recent phase II study demonstrated an improvement in symptoms at 1 month after singledose RT ( 8 Gy in one fraction) in approximately $50 \%$ of patients with end-stage HCC causing substantial pain or discomfort [22]. This is promising and has prompted a phase III study (HE1) of palliative RT for symptomatic HCC and liver metastases that is currently recruiting [23]. This Canadian study will assess the quality of life and symptom control for highly symptomatic end-stage patients with HCC. Patients will be randomized to either RT alone or best supportive care, with an option to cross over at 1 month to receive RT for patients randomized to best supportive care. This study is powered to detect a large difference in symptom improvement from single-dose RT.

To summarize, the importance of RT at every stage of HCC management is increasing, even though the stigma associated with potential toxicity has stalled the development of randomized trials and the incorporation of RT into treatment guidelines.

\section{Interstitial Treatments: The Western Perspective}

In recent years, nonrandomized studies have reported similar outcomes for both the local control rate and OS for patients with very early stage HCCs (smaller than $2 \mathrm{~cm}$ ) who underwent hepatic resection or ablation [24]. Accordingly, nodules in the 2-cm size range that are neither subcapsular nor perivascular are the ideal target for percutaneous ablation, which is considered to be the standard technique at most institutions. For such nodules, percutaneous ablation achieved a complete response rate approaching $97 \%$ and 5-year survival rates of 65-68\% [25]. For patients with early stage HCC - either a single tumor smaller than $5 \mathrm{~cm}$ or up to three nodules each smaller than $3 \mathrm{~cm}$, with no evidence of vascular invasion or extrahepatic spread, performance status 0 , and class A or B cirrhosis - who can undergo any of the available curative therapies (i.e., surgical resection, liver transplantation, and image-guided ablation), the randomized trials comparing ablation and surgery reported to date have failed to demonstrate the superiority of either therapy. In general, when the first HCC develops, ablation is recommended when surgical options are precluded or severely challenging. However, for local tumor progression after resection and for distant recurrences (which occur in as many as $50-60 \%$ of patients with Hepatitis C Virus (HCV)-related cirrhosis during their lifetime), ablation is the first-line treatment when nodules are in a suitable and safe location for percutaneous targeting.

Recent reports on the long-term outcomes of patients treated with ablation have shown that in patients with Child-Pugh class A cirrhosis and early stage HCC, 5-year survival rates 
Table 2. Results of the major Western series of HCC treated by MWA, RFA, or IRE

\begin{tabular}{|c|c|c|c|c|c|c|c|c|}
\hline $\begin{array}{l}\text { Author, year } \\
\text { [reference] }\end{array}$ & $\begin{array}{l}\text { Number of } \\
\text { patients/ } \\
\text { nodules }\end{array}$ & $\begin{array}{l}\text { Tumor size } \\
(\mathrm{cm})^{*}\end{array}$ & CAR & LRR & 1-Y DFS & 5-Y DFS & $1-Y$ OS & $5-Y$ OS \\
\hline $\begin{array}{l}\text { Niessen, } 2016 \\
{[32]}\end{array}$ & $\begin{array}{l}\text { IRE: } \\
34 / 65\end{array}$ & $\begin{array}{l}\text { IRE: } 2.4 ; \\
0.2-7.1\end{array}$ & $\begin{array}{l}\text { IRE: } \\
81.5 \%\end{array}$ & $\begin{array}{l}\text { IRE: } \\
35 \%\end{array}$ & n.a. & n.a. & n.a. & n.a. \\
\hline $\begin{array}{l}\text { Cannon, } 2013 \\
\text { [33] }\end{array}$ & $\begin{array}{l}\text { IRE: } \\
14 / 18\end{array}$ & $\begin{array}{l}\text { IRE: } 2.1 ; \\
1.3-4.5\end{array}$ & $\begin{array}{l}\text { IRE: } \\
83 \%\end{array}$ & $\begin{array}{l}\text { IRE: } \\
50 \%\end{array}$ & n.a. & n.a. & n.a. & n.a. \\
\hline $\begin{array}{l}\text { Cheung, } 2013 \\
{[34]}\end{array}$ & $\begin{array}{l}\text { IRE: } \\
11 / 18\end{array}$ & $\begin{array}{l}\text { IRE: } 2.0 ; \\
1.0-6.1\end{array}$ & $\begin{array}{l}\text { IRE: } \\
72 \%\end{array}$ & $\begin{array}{l}\text { IRE: } \\
0 \%\end{array}$ & $\begin{array}{l}\text { RFA: } \\
96 \% \\
\text { MWA: } \\
97 \%\end{array}$ & n.a. & n.a. & n.a. \\
\hline $\begin{array}{l}\text { Vogl, } 2015 \\
\text { [31] }\end{array}$ & $\begin{array}{l}\text { RFA: } \\
\text { 25/32 } \\
\text { MWA: } \\
\text { 28/36 }\end{array}$ & $\begin{array}{l}\text { RFA: 3.2; } \\
0.8-4.5 \\
\text { MWA: 3.6; } \\
0.9-5\end{array}$ & $\begin{array}{l}\text { RFA: } \\
84 \% \\
\text { MWA: } \\
89 \%\end{array}$ & $\begin{array}{l}\text { RFA: } \\
3 \% \\
\text { MWA: } \\
3 \%\end{array}$ & n.a. & n.a & $\begin{array}{l}\text { RFA: } \\
\text { 100\% } \\
\text { MWA: } \\
100 \%\end{array}$ & n.a. \\
\hline $\begin{array}{l}\text { Groeschl, } 2014 \\
\text { [35] }\end{array}$ & $\begin{array}{l}\text { MWA: } \\
139\end{array}$ & $\begin{array}{l}\text { MWA: 2.6; } \\
0.7-6\end{array}$ & $\begin{array}{l}\text { MWA: } \\
94 \%\end{array}$ & $\begin{array}{l}\text { MWA: } \\
10 \%\end{array}$ & n.a. & $\begin{array}{l}\text { MWA: } \\
7 \%\end{array}$ & n.a. & $\begin{array}{l}\text { MWA: } \\
19 \%\end{array}$ \\
\hline $\begin{array}{l}\text { N'Kontcho, } 2009 \\
{[36]}\end{array}$ & $\begin{array}{l}\text { RFA: } \\
235 \\
\end{array}$ & $\begin{array}{l}\text { RFA: 2.92; } \\
\pm 1^{* *}\end{array}$ & $\begin{array}{l}\text { RFA: } \\
95 \%\end{array}$ & $\begin{array}{l}\text { RFA: } \\
11 \%\end{array}$ & n.a. & $\begin{array}{l}\text { RFA: } \\
32 \%\end{array}$ & n.a. & $\begin{array}{l}\text { RFA: } \\
30 \%\end{array}$ \\
\hline
\end{tabular}

$\mathrm{CAR}=$ complete ablation rate; LRR=local recurrence rate; n.a.= not available. *Values are the median and range; ${ }^{* *}$ Values are the mean and standard deviation.

are as high as $51-64 \%$ and may reach $76 \%$ in patients who meet the Barcelona Clinic Liver Cancer (BCLC) criteria for surgical resection [26-28]. Among the ablative methods, RFA still has the largest diffusion worldwide, but high-power-microwave (MW) technology, recently introduced to clinical practice, is able to overcome some specific limitations of RFA. Thanks to their physical properties, MWs achieve much higher tissue temperatures and, accordingly, achieve larger, more rounded, and regularly demarcated volumes of necrosis in a shorter time. Thus, in HCCs larger than 2-3 cm and/or multiple nodules, microwave ablation (MWA) has enabled a significantly increased rate of complete ablation compared to that achieved with RFA. MWA will likely lead to "raising the bar" for HCCs routinely treatable with ablation as an alternative to resection for HCCs from $2-3 \mathrm{~cm}$, provided that the location is suitable and safe [29-31]. An additional clinically available ablative technique is irreversible electroporation (IRE). This approach opens new scenarios for the ablative treatment of small HCCs located in the vicinity of bile ducts or near the stomach, duodenum, or colon, i.e., in locations absolutely unsuitable for RFA.

Case series and cohort studies have demonstrated that locoregional therapies may reduce the drop-out rate of HCC patients on the waiting list for liver transplantation to $0-25 \%$. For this purpose, RFA is the most commonly used bridging therapy in patients with a single HCC in a suitable location for percutaneous targeting, whereas MWA is chosen over RFA in cases with increased risk of heat-sink effects. TACE is also frequently used in the other cases, particularly when HCCs are multiple and bilobar.

Table 2 details the results of major Western series of HCC treated by MWA, RFA, or IRE [31-36]. As depicted, the results for MWA and RFA are comparable, whereas IRE is associated with inferior local control. However, the experience with IRE is still limited, and better results are expected in the future. Note that the long-term outcome (DFS and OS) associated with these three techniques are not truly comparable because the studies included different patient groups. 


\section{Interstitial Treatments: The Eastern Perspective}

Among the various nonsurgical therapies for HCC, image-guided percutaneous ablation is considered best for early stage HCC. Ablation has been widely performed in HCC patients, generally for those with Child-Pugh class A or B who have three or fewer tumors, each $3 \mathrm{~cm}$ or less in diameter. Ethanol injection (EI) was formerly the standard procedure among the various percutaneous ablation techniques [37]. However, randomized controlled trials have demonstrated that RFA is superior to EI. RFA has a 46\% smaller risk of death (adjusted relative risk, 0.54 [95\% CI: 0.33-0.89], $\mathrm{p}=0.02$ ) and an 88\% smaller risk of local tumor progression (relative risk, 0.12 [95\% CI: 0.03-0.55], $\mathrm{p}=0.006$ ) than EI does [38].

In the author's (SS) 10-year experience with RFA, final CTs showed complete tumor ablation in 2964 (99.4\%) of 2982 treatments performed in 1170 primary HCC patients. With a median follow-up of 38.2 months, 5- and 10-year survival rates were 60.2\% (95\% CI 56.7$63.9 \%$ ) and $27.3 \%$ (95\% CI 21.5-34.7\%), respectively. Multivariate analysis demonstrated that age, HCV infection, Child-Pugh class, tumor size, tumor number, the serum des-gamma-carboxy-prothrombin (DCP) level, and the serum lectin-reactive alpha-fetoprotein level (AFP-L3, one of the three AFP glycoforms which is highly specific for HCC even at early stage) were significantly related to survival. The 5 - and 10 -year local tumor progression rates (LTP) were both $3.2 \%$ (95\% CI 2.1-4.3\%). The serum DCP level alone was significantly related to local tumor progression. The 5- and 10-year distant recurrence rates were $74.8 \%$ (95\% CI 71.8-77.8\%) and 80.8\% (95\% CI 77.4-84.3\%), respectively. HCV infection, Child-Pugh class, platelet count, tumor size, tumor number, serum AFP level, and serum DCP level were significantly related to distant recurrence [39]. Our results showed that RFA can be curative and can achieve long-term survival. A nationwide survey in Japan also showed similar OS between RFA and surgical resection.

Various innovations, such as contrast-enhanced ultrasound and multimodality fusion imaging, will likely further improve outcomes for percutaneous ablation. Sophisticated RFA is potentially curative, minimally invasive, and easily repeatable in case of recurrence, and might be superior to surgery in the treatment of small and middle-sized HCC.

Table 3 details the results of the major Eastern series of HCC treated by MWA and RFA. There is no experience with IRE in Eastern institutions. As with the Western experience, the results of MWA and RFA in terms of local control are comparable [39-44]. And again, the longterm outcomes (DFS and OS) of these studies were not comparable because they included different types of patients.

\section{Conclusions}

There is an emerging role for interventional oncology in the treatment of HCC, either as treatment alone, a bridge to transplantation, or associated with other approaches. Modern SBRT and interstitial therapies such as RFA, MWA, and IRE deserve consideration for inclusion in therapy guidelines, and not just for early HCC. 
Donadon et al.: Interventional Oncology for HCC

Table 3. Results of the major Eastern series of HCC treated by MWA or RFA

\begin{tabular}{|c|c|c|c|c|c|c|c|c|}
\hline $\begin{array}{l}\text { Author, year } \\
\text { [reference] }\end{array}$ & $\begin{array}{l}\text { Number of } \\
\text { patients/ } \\
\text { nodules }\end{array}$ & $\begin{array}{l}\text { Tumor size } \\
(\mathrm{cm})^{*}\end{array}$ & CAR & LTP & 1-Y DFS & 5-Y DFS & $1-Y$ OS & $5-Y$ OS \\
\hline $\begin{array}{l}\text { Zhang, } 2013 \\
{[40]}\end{array}$ & $\begin{array}{l}\text { RFA: } \\
\text { 78/97 } \\
\text { MWA: } \\
\text { 77/105 }\end{array}$ & $\begin{array}{l}\text { RFA: } 2.3 \text {; } \\
0.8-5 \\
\text { MWA: 2.2; } \\
0.9-5\end{array}$ & $\begin{array}{l}\text { RFA: } \\
83 \% \\
\text { MWA: } \\
87 \%\end{array}$ & $\begin{array}{l}\text { RFA: } \\
12 \% \\
\text { MWA: } \\
10 \%\end{array}$ & $\begin{array}{l}\text { RFA: } \\
70 \% \\
\text { MWA: } \\
62 \%\end{array}$ & $\begin{array}{l}\text { RFA: } \\
34 \% \\
\text { MWA: } \\
21 \%\end{array}$ & $\begin{array}{l}\text { RFA: } \\
91 \% \\
\text { MWA: } \\
92 \%\end{array}$ & $\begin{array}{l}\text { RFA: } \\
41 \% \\
\text { MWA: } \\
38 \%\end{array}$ \\
\hline $\begin{array}{l}\text { Ding, } 2013 \\
{[41]}\end{array}$ & $\begin{array}{l}\text { RFA: } \\
85 / 98 \\
\text { MWA: } \\
113 / 131\end{array}$ & $\begin{array}{l}\text { RFA: 2.38; } \\
1-4.8 \\
\text { MWA: } 2.55 \\
0.8-5\end{array}$ & $\begin{array}{l}\text { RFA: } \\
99 \% \\
\text { MWA: } \\
98 \%\end{array}$ & $\begin{array}{l}\text { RFA: } \\
5 \% \\
\text { MWA: } \\
10 \%\end{array}$ & $\begin{array}{l}\text { RFA: } \\
80 \% \\
\text { MWA: } \\
75 \%\end{array}$ & $\begin{array}{l}\text { RFA: } \\
19 \% \\
\text { MWA: } \\
16 \%\end{array}$ & $\begin{array}{l}\text { RFA: } \\
99 \% \\
\text { MWA: } \\
98 \%\end{array}$ & $\begin{array}{l}\text { RFA: } \\
78 \% \\
\text { MWA: } \\
78 \%\end{array}$ \\
\hline $\begin{array}{l}\text { Shiina, } 2012 \\
\text { [39] }\end{array}$ & $\begin{array}{l}\text { RFA: } \\
1170 / 2982\end{array}$ & $\begin{array}{l}\text { RFA: } \\
2.54 \pm 1.04^{* *}\end{array}$ & $\begin{array}{l}\text { RFA: } \\
99 \%\end{array}$ & $\begin{array}{l}\text { RFA: } \\
3 \%\end{array}$ & $\begin{array}{l}\text { RFA: } \\
73 \%\end{array}$ & $\begin{array}{l}\text { RFA: } \\
22 \%\end{array}$ & $\begin{array}{l}\text { RFA: } \\
97 \%\end{array}$ & $\begin{array}{l}\text { RFA: } \\
60 \%\end{array}$ \\
\hline $\begin{array}{l}\text { Ohmoto, } 2009 \\
\text { [42] }\end{array}$ & $\begin{array}{l}\text { RFA: } \\
34 / 37 \\
\text { MWA: } \\
49 / 56\end{array}$ & $\begin{array}{l}\text { RFA: } 1.6 ; \\
0.7-2 \\
\text { MWA: } 1.7 ; \\
0.8-2\end{array}$ & n.a. & $\begin{array}{l}\text { RFA: } \\
9 \% \\
\text { MWA: } \\
19 \%\end{array}$ & $\begin{array}{l}\text { RFA: } \\
63 \% \\
\text { MWA: } \\
52 \%\end{array}$ & $\begin{array}{l}\text { RFA: } \\
26 \% \\
\text { MWA: } \\
3 \%\end{array}$ & $\begin{array}{l}\text { RFA: } \\
\text { 100\% } \\
\text { MWA: } \\
89 \%\end{array}$ & $\begin{array}{l}\text { RFA: } \\
70 \% \\
\text { MWA: } \\
39 \%\end{array}$ \\
\hline $\begin{array}{l}\mathrm{Lu}, 2005 \\
{[43]}\end{array}$ & $\begin{array}{l}\text { RFA: } \\
\text { 53/98 } \\
\text { MWA: } \\
49 / 72\end{array}$ & $\begin{array}{l}\text { RFA: } 2.6 ; \\
1-6.1 \\
\text { MWA: } 1.7 ; \\
0.9-7.2\end{array}$ & $\begin{array}{l}\text { RFA: } \\
93 \% \\
\text { MWA: } \\
95 \%\end{array}$ & $\begin{array}{l}\text { RFA: } \\
21 \% \\
\text { MWA: } \\
12 \%\end{array}$ & $\begin{array}{l}\text { RFA: } \\
37 \% \\
\text { MWA: } \\
46 \%\end{array}$ & $\begin{array}{l}\text { RFA: } \\
\text { n.a. } \\
\text { MWA: } \\
13 \%\end{array}$ & $\begin{array}{l}\text { RFA: } \\
72 \% \\
\text { MWA: } \\
82 \%\end{array}$ & $\begin{array}{l}\text { RFA: } \\
37 \% \\
\text { MWA: } \\
24 \%\end{array}$ \\
\hline $\begin{array}{l}\text { Shibata, } 2002 \\
\text { [44] }\end{array}$ & $\begin{array}{l}\text { RFA: } \\
\text { 36/48 } \\
\text { MWA: } \\
36 / 46\end{array}$ & $\begin{array}{l}\text { RFA: 2.3; } \\
\text { 1-3.7 } \\
\text { MWA: 2.2; } \\
0.9-3.4\end{array}$ & $\begin{array}{l}\text { RFA: } \\
96 \% \\
\text { MWA: } \\
89 \%\end{array}$ & $\begin{array}{l}\text { RFA: } \\
12 \% \\
\text { MWA: } \\
24 \%\end{array}$ & n.a. & n.a. & n.a. & n.a. \\
\hline
\end{tabular}

$\mathrm{CAR}=$ complete ablation rate. *Values are the median and range; **Values are the mean and standard deviation.

\section{Conflicts of Interest}

The authors declare no conflicts of interest.

\section{References}

1 Venook AP, Papandreou C, Furuse J, de Guevara LL: The incidence and epidemiology of hepatocellular carcinoma: a global and regional perspective. Oncologist 2010;15(Suppl 4):5-13.

2 Mazzaferro V, Llovet JM, Miceli R, Bhoori S, Schiavo M, Mariani L, Camerini T, Roayaie S, Schwartz ME, Grazi GL, Adam R, Neuhaus P, Salizzoni M, Bruix J, Forner A, De Carlis L, Cillo U, Burroughs AK, Troisi R, Rossi M, Gerunda GE, Lerut J, Belghiti J, Boin I, Gugenheim J, Rochling F, Van Hoek B, Majno P, Metroticket Investigator Study Group: Predicting survival after liver transplantation in patients with hepatocellular carcinoma beyond the Milan criteria: a retrospective, exploratory analysis. Lancet Oncol 2009;10:35-43.

3 Torzilli G, Belghiti J, Kokudo N, Takayama T, Capussotti L, Nuzzo G, Vauthey JN, Choti MA, De Santibanes E, Donadon M, Morenghi E, Makuuchi M: A snapshot of the effective indications and results of surgery for hepatocellular carcinoma in tertiary referral centers: is it adherent to the EASL/AASLD recommendations?: an observational study of the HCC East-West study group. Ann Surg 2013;257:929-937.

4 Andolino DL, Johnson CS, Maluccio M, Kwo P, Tector AJ, Zook J, Johnstone PA, Cardenes HR: Stereotactic body radiotherapy for primary hepatocellular carcinoma. Int J Radiat Oncol Biol Phys 2011;81:e447e453.

5 Katz AW, Chawla S, Qu Z, Kashyap R, Milano MT, Hezel AF: Stereotactic hypofractionated radiation therapy as a bridge to transplantation for hepatocellular carcinoma: clinical outcome and pathologic correlation. Int J Radiat Oncol Biol Phys 2012;83:895-900.

6 Sandroussi C, Dawson LA, Lee M, Guindi M, Fischer S, Ghanekar A, Cattral MS, McGilvray ID, Levy GA, Renner E, Greig PD, Grant DR: Radiotherapy as a bridge to liver transplantation for hepatocellular carcinoma. Transpl Int 2010;23:299-306. 
7 Sapisochin G, Goldaracena N, Doherty M, Russo M, Laurence J, Dib M, Barbas A, Konx JJ, McGilvray ID, Ghanekar A, Cattral MS, Selzner M, Greig PD, Dawson LD, Grant DR: Is stereotactic body radiotherapy, as a bridge to liver transplantation, as effective as TACE? Transplantation 2015;99(S1):120.

8 Sanuki N, Takeda A, Oku Y, Mizuno T, Aoki Y, Eriguchi T, Iwabuchi S, Kunieda E: Stereotactic body radiotherapy for small hepatocellular carcinoma: a retrospective outcome analysis in 185 patients. Acta Oncol 2014;53:399-404.

9 Yoon SM, Lim YS, Park MJ, Kim SY, Cho B, Shim JH, Kim KM, Lee HC, Chung YH, Lee YS, Lee SG, Lee YS, Park JH, Kim JH: Stereotactic body radiation therapy as an alternative treatment for small hepatocellular carcinoma. PLoS One 2013;8:e79854.

10 Kwon JH, Bae SH, Kim JY, Choi BO, Jang HS, Jang JW, Choi JY, Yoon SK, Chung KW: Long-term effect of stereotactic body radiation therapy for primary hepatocellular carcinoma ineligible for local ablation therapy or surgical resection. Stereotactic radiotherapy for liver cancer. BMC Cancer 2010;10:475.

11 Kawashima M, Furuse J, Nishio T, Konishi M, Ishii H, Kinoshita T, Nagase M, Nihei K, Ogino T: Phase II study of radiotherapy employing proton beam for hepatocellular carcinoma. J Clin Oncol 2005;23:1839-1846.

12 Guo WJ, Yu EX, Liu LM, Li J, Chen Z, Lin JH, Meng ZQ, Feng Y: Comparison between chemoembolization combined with radiotherapy and chemoembolization alone for large hepatocellular carcinoma. World J Gastroenterol 2003;9:1697-1701.

13 Meng MB, Cui YL, Lu Y, She B, Chen Y, Guan YS, Zhang RM: Transcatheter arterial chemoembolization in combination with radiotherapy for unresectable hepatocellular carcinoma: a systematic review and metaanalysis. Radiother Oncol 2009;92:184-194.

14 Lin CS, Jen YM, Chiu SY, Hwang JM, Chao HL, Lin HY, Shum WY: Treatment of portal vein tumor thrombosis of hepatoma patients with either stereotactic radiotherapy or three-dimensional conformal radiotherapy. Jpn J Clin Oncol 2006;36:212-217.

15 Bujold A, Massey CA, Kim JJ, Brierley J, Cho C, Wong RK, Dinniwell RE, Kassam Z, Ringash J, Cummings B, Sykes J, Sherman M, Knox JJ, Dawson LA: Outcomes following sequential trials of stereotactic body radiotherapy (SBRT) for hepatocellular carcinoma (HCC). ASCO Annual Meeting. Chicago, IL; 2011.

16 Rim CH, Yang DS, Park YJ, Yoon WS, Lee JA, Kim CY: Effectiveness of high-dose three-dimensional conformal radiotherapy in hepatocellular carcinoma with portal vein thrombosis. Jpn J Clin Oncol 2012;42:721-729.

17 Shim SJ, Seong J, Han KH, Chon CY, Suh CO, Lee JT: Local radiotherapy as a complement to incomplete transcatheter arterial chemoembolization in locally advanced hepatocellular carcinoma. Liver Int 2005;25:1189-1196.

18 Cheng AL, Kang YK, Chen Z, Tsao CJ, Qin S, Kim JS, Luo R, Feng J, Ye S, Yang TS, Xu J, Sun Y, Liang H, Liu J, Wang J, Tak WY, Pan H, Burock K, Zou J, Voliotis D, Guan Z: Efficacy and safety of sorafenib in patients in the Asia-Pacific region with advanced hepatocellular carcinoma: a phase III randomised, double-blind, placebo-controlled trial. Lancet Oncol 2009;10:25-34.

19 Brade AM, Kim J, Brierley J, Dinniwell R, Wong R, Cho C, Kassam Z, Joshua A, Knox J, Dawson LA: Phase I study of sorafenib and whole-liver radiation therapy (WLRT) or stereotactic body radiation therapy (SBRT) for liver metastases. Int J Radiat Oncol Biol Phys 2012;84:S11-S12.

20 Chen SW, Lin LC, Kuo YC, Liang JA, Kuo CC, Chiou JF: Phase 2 study of combined sorafenib and radiation therapy in patients with advanced hepatocellular carcinoma. Int J Radiat Oncol Biol Phys 2014;88:10411047.

21 https://clinicaltrials.gov/ct2/show/NCT01730937?term=RTOG+1112\&rank=2.

22 Soliman H, Ringash J, Jiang H, Singh K, Kim J, Dinniwell R, Brade A, Wong R, Brierley J, Cummings B, Zimmermann C, Dawson LA: Phase II trial of palliative radiotherapy for hepatocellular carcinoma and liver metastases. J Clin Oncol 2013;31:3980-3986.

23 https://clinicaltrials.gov/ct2/show/NCT02511522?term=He1\&rank=2.

24 Livraghi T, Meloni F, Di Stasi M, Rolle E, Solbiati L, Tinelli C, Rossi S: Sustained complete response and complications rates after radiofrequency ablation of very early hepatocellular carcinoma in cirrhosis: Is resection still the treatment of choice? Hepatology 2008;47:82-89.

25 Lencioni R, Crocetti L: Local-regional treatment of hepatocellular carcinoma. Radiology 2012;262:43-58.

26 Hasegawa K, Kokudo N, Makuuchi M, Izumi N, Ichida T, Kudo M, Ku Y, Sakamoto M, Nakashima O, Matsui O, Matsuyama Y: Comparison of resection and ablation for hepatocellular carcinoma: a cohort study based on a Japanese nationwide survey. J Hepatol 2013;58:724-729.

27 Huang J, Yan L, Cheng Z, Wu H, Du L, Wang J, Xu Y, Zeng Y: A randomized trial comparing radiofrequency ablation and surgical resection for HCC conforming to the Milan criteria. Ann Surg 2010;252:903-912.

28 Pompili M, Saviano A, de Matthaeis N, Cucchetti A, Ardito F, Federico B, Brunello F, Pinna AD, Giorgio A, Giulini SM, De Sio I, Torzilli G, Fornari F, Capussotti L, Guglielmi A, Piscaglia F, Aldrighetti L, Caturelli E, Calise F, Nuzzo G, Rapaccini GL, Giuliante F: Long-term effectiveness of resection and radiofrequency ablation for single hepatocellular carcinoma $\leq 3 \mathrm{~cm}$. Results of a multicenter Italian survey. J Hepatol 2013;59:89-97.

29 Leung U, Kuk D, D’Angelica MI, Kingham TP, Allen PJ, DeMatteo RP, Jarnagin WR, Fong Y: Long-term outcomes following microwave ablation for liver malignancies. Br J Surg 2015;102:85-91.

30 Poggi G, Tosoratti N, Montagna B, Picchi C: Microwave ablation of hepatocellular carcinoma. World J Hepatol 2015;7:2578-2589.

31 Vogl TJ, Farshid P, Naguib NN, Zanos S, Bodelle B, Paul J, Mbalisike EC, Beeres M, Nour-Eldin NE: Ablation therapy of hepatocellular carcinoma: a comparative study between radiofrequency and microwave ablation. Abdom Imaging 2015;40:1829-1837. 
32 Niessen C, Jung EM, Wohlgemuth WA, Trabold B, Haimerl M, Schreyer A, Stroszczynski C, Wiggermann P: Irreversible electroporation of a hepatocellular carcinoma lesion adjacent to a transjugular intrahepatic portosystemic shunt stent graft. Korean J Radiol 2013;14:797-800.

33 Cannon R, Ellis S, Hayes D, Narayanan G, Martin RC 2nd: Safety and early efficacy of irreversible electroporation for hepatic tumors in proximity to vital structures. J Surg Oncol 2013;107:544-549.

34 Cheung W, Kavnoudias H, Roberts S, Szkandera B, Kemp W, Thomson KR: Irreversible electroporation for unresectable hepatocellular carcinoma: initial experience and review of safety and outcomes. Technol Cancer Res Treat 2013;12:233-241.

35 Groeschl RT, Pilgrim CH, Hanna EM, Simo KA, Swan RZ, Sindram D, Martinie JB, Iannitti DA, Bloomston M, Schmidt C, Khabiri H, Shirley LA, Martin RC, Tsai S, Turaga KK, Christians KK, Rilling WS, Gamblin TC: Microwave ablation for hepatic malignancies: a multiinstitutional analysis. Ann Surg 2014;259:1195-1200.

36 N'Kontchou G, Mahamoudi A, Aout M, Ganne-Carrié N, Grando V, Coderc E, Vicaut E, Trinchet JC, Sellier N, Beaugrand M, Seror 0: Radiofrequency ablation of hepatocellular carcinoma: long-term results and prognostic factors in 235 Western patients with cirrhosis. Hepatology 2009;50:1475-1483.

37 Shiina S, Tateishi R, Imamura M, Teratani T, Koike Y, Sato S, Obi S, Kanai F, Kato N, Yoshida H, Omata M, Koike K: Percutaneous ethanol injection for hepatocellular carcinoma: 20-year outcome and prognostic factors. Liver Int 2012;32:1434-1442.

38 Shiina S, Teratani T, Obi S, Sato S, Tateishi R, Fujishima T, Ishikawa T, Koike Y, Yoshida H, Kawabe T, Omata M: A randomized controlled trial of radiofrequency ablation with ethanol injection for small hepatocellular carcinoma. Gastroenterology 2005;129:122-130.

39 Shiina S, Tateishi R, Arano T, Uchino K, Enooku K, Nakagawa H, Asaoka Y, Sato T, Masuzaki R, Kondo Y, Goto T, Yoshida H, Omata M, Koike K: Radiofrequency ablation for hepatocellular carcinoma: 10-year outcome and prognostic factors. Am J Gastroenterol 2012;107:569-577, quiz 578.

40 Zhang L, Wang N, Shen Q, Cheng W, Qian GJ: Therapeutic efficacy of percutaneous radiofrequency ablation versus microwave ablation for hepatocellular carcinoma. PLoS One 2013;8:e76119.

41 Ding J, Jing X, Liu J, Wang Y, Wang F, Wang Y, Du Z: Comparison of two different thermal techniques for the treatment of hepatocellular carcinoma. Eur J Radiol 2013;82:1379-1384.

42 Ohmoto K, Yoshioka N, Tomiyama Y, Shibata N, Kawase T, Yoshida K, Kuboki M, Yamamoto S: Comparison of therapeutic effects between radiofrequency ablation and percutaneous microwave coagulation therapy for small hepatocellular carcinomas. J Gastroenterol Hepatol 2009;24:223-227.

43 Lu MD, Xu HX, Xie XY, Yin XY, Chen JW, Kuang M, Xu ZF, Liu GJ, Zheng YL: Percutaneous microwave and radiofrequency ablation for hepatocellular carcinoma: a retrospective comparative study. J Gastroenterol 2005;40:1054-1060.

44 Shibata T, Iimuro Y, Yamamoto Y, Maetani Y, Ametani F, Itoh K, Konishi J: Small hepatocellular carcinoma: comparison of radio-frequency ablation and percutaneous microwave coagulation therapy. Radiology 2002;223:331-337. 